\title{
Pasteurella Cerebral Mycotic Aneurysm: A Case Report and Review of the Literature
}

Vidya S. Kollu ${ }^{1}$, Lennox Archibald ${ }^{1}$, Matthew Edwards ${ }^{2}$, Jennifer W. Janelle ${ }^{1}$, Kyung W. Hong ${ }^{1}$, Gautam Kalyatanda 1

1. Department of Infectious Diseases and Global Medicine, College of Medicine, University of Florida, Gainesville, USA 2. Department of Infectious Diseases, Case Western Reserve University School of Medicine, Cleveland, USA

Corresponding author: Vidya S. Kollu, vskollu@gmail.com

\begin{abstract}
Pasteurella species (spp.) are pleomorphic, Gram-negative, facultatively anaerobic bacilli commonly found in the upper respiratory tract and oral cavities of wild and domesticated animals such as dogs and cats. Pasteurella spp. infections in humans are typically caused by animal bites or scratches, or other inadvertent exposure of an open skin lesion to oral secretions of the animal. While skin and soft tissue infections are relatively common, respiratory infections, endocarditis, osteomyelitis, meningitis, and mycotic aneurysms have also been documented. To date, nine cases of mycotic aneurysms caused by Pasteurella spp. have been reported. However, only one of those cases has involved a cerebral mycotic aneurysm, and it had a fatal outcome. This report describes a successfully managed Pasteurella cerebral mycotic aneurysm that had occurred as a complication of underlying mitral valve endocarditis.
\end{abstract}

Categories: Internal Medicine, Infectious Disease, Neurosurgery

Keywords: mycotic aneurysm, infective endocarditis, pasteurella infection, intracranial hemorrhage, cerebral aneurysm

\section{Introduction}

Pasteurella species (spp.) are pleomorphic, facultatively anaerobic, Gram-negative bacilli, which were first isolated by Louis Pasteur in 1880. These bacteria are commonly found in the upper respiratory tract and oral cavities of wild and domesticated animals, including dogs and cats [1]. Pasteurella spp. typically cause infections among humans following transmission via an animal bite, scratch, or lick, or by inhalation of infected secretions [2]. Also, rare cases of human-to-human and vertical transmission have also been described [3]. Pasteurella spp. commonly cause infection on the skin and soft tissues [2]. Rare invasive infections due to Pasteurella spp., including respiratory infections, endocarditis, osteomyelitis, meningitis, and mycotic aneurysms, arise almost exclusively among susceptible individuals including the immunocompromised, elderly, and neonates [2]. In this report, we present a rare case of a ruptured cerebral mycotic aneurysm complicating prosthetic valve endocarditis caused by Pasteurella spp. To the best of our knowledge, this is the second reported case of Pasteurella cerebral mycotic aneurysm and the first one with a successful outcome.

Review began 05/16/2021 Review ended 05/19/2021 Published 05/29/2021

\section{() Copyright 2021}

Kollu et al. This is an open access article distributed under the terms of the Creative Commons Attribution License CC-BY 4.0., which permits unrestricted use, distribution, and reproduction in any medium, provided the original author and source are credited.

\section{Case Presentation}

A 57-year-old woman with a past medical history of atrial fibrillation, hypertension, cervical spine injury with C5-C6 fusion, congestive heart failure, and mitral valve endocarditis status post mechanical mitral valve replacement seven years ago presented with sudden onset of left-sided weakness and an inability to stand. These symptoms were associated with a two-week history of fever, chills, myalgia, and anorexia. She denied headache, nausea, vomiting, chest pain, or shortness of breath. On examination, the patient's temperature was $37^{\circ} \mathrm{C}\left(98.6^{\circ} \mathrm{F}\right)$, pulse rate was 73 beats per minute, respiratory rate was 19 breaths per minute, and blood pressure was $166 / 63 \mathrm{mmHg}$. She was saturating at $98 \%$ on ambient room air. The cardiovascular exam revealed a grade $2 / 6$ systolic murmur and grade 3 pedal edema. The oral exam showed absent dentition, and the musculoskeletal exam revealed bilateral palmar Dupuytren's contractures and multiple scratch wounds on the lower extremities with no evidence of cellulitis or lymphangitis. The central nervous system exam revealed left-sided hemiparesis. The rest of the physical examination was unremarkable. Her social history was significant for a 25 pack-year history of smoking (she had quit 15 years ago), occasional alcohol use, and no illicit drug use. She admitted to sustaining scratch injuries while playing with her two dogs; further questioning revealed that the dogs had subsequently licked the wounds.

Laboratory testing showed a normal white blood cell count of $5.2 \times 10^{9} / \mathrm{L}$ (normal range: $4.0-10.0 \times 10^{9} / \mathrm{L}$ ), low hemoglobin of $10.4 \mathrm{gm} / \mathrm{dL}$ (normal range: $12.0-16.0 \mathrm{gm} / \mathrm{dL}$ ), and hematocrit of $31.5 \%$ (normal range: 35 $45 \%)$. The basic metabolic panel was within normal limits. Chest radiography revealed bibasilar subsegmental atelectasis with a minimal left pleural effusion. CT of the head revealed a large right frontal hematoma with midline shift (Figure 1), and CT angiogram indicated active extravasation of contrast. 


\section{Cureus}

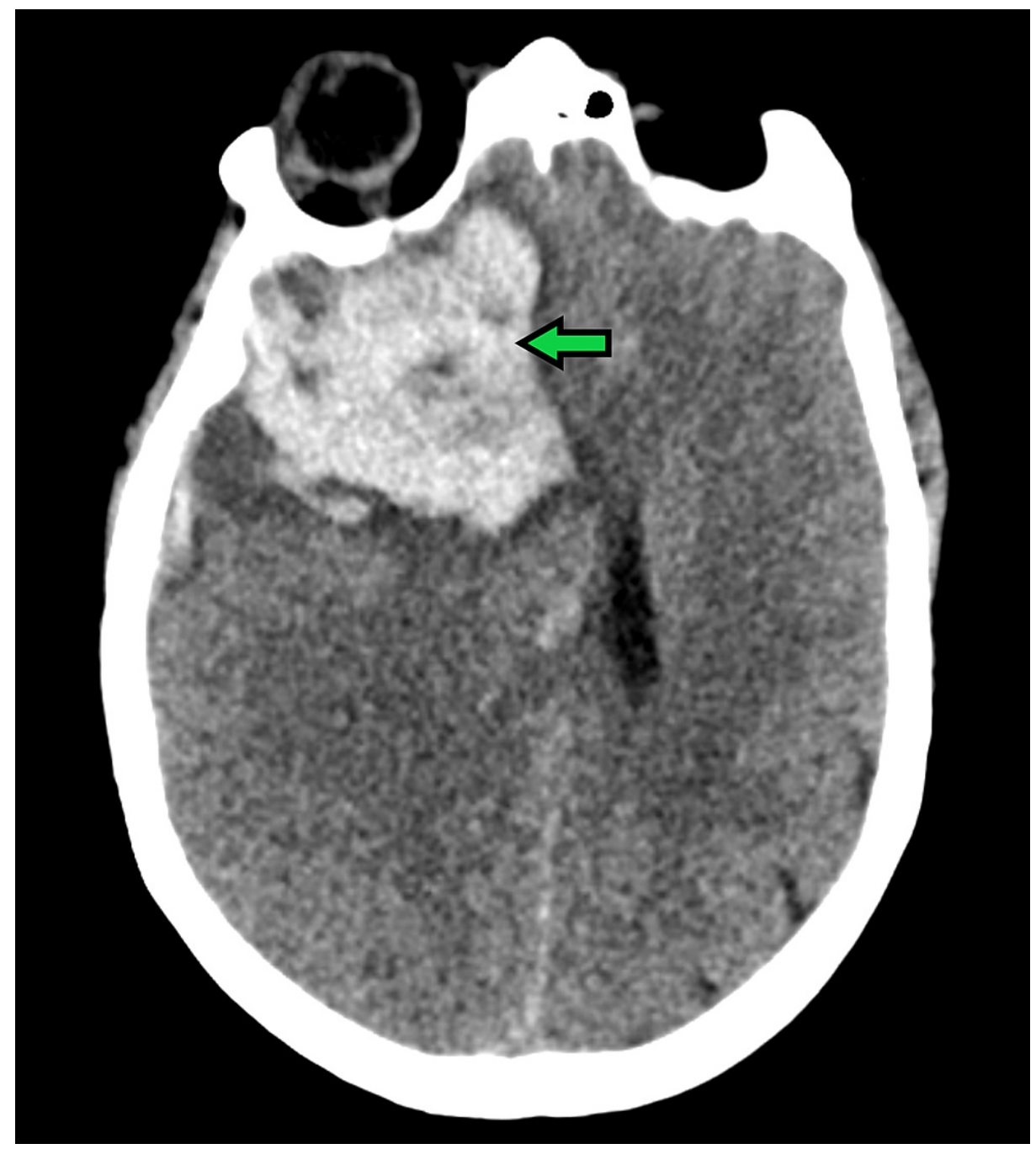

FIGURE 1: CT of the head showing a large right frontal hematoma with midline shift (arrow)

CT: computed tomography

The patient underwent emergent craniotomy with hematoma evacuation. A mycotic aneurysm with cerebritis was found intraoperatively, and the aneurysm was clipped. An external ventricular device (EVD) was placed. She remained intubated and was started on broad-spectrum antimicrobial therapy, including intravenous (IV) vancomycin and cefepime. Blood cultures yielded growth of Pasteurella spp., which were susceptible to all antibiotics tested. Minimum inhibitory concentrations (MIC) were as shown in Table 1. 


\section{Cureus}

\begin{tabular}{|c|c|c|}
\hline Antibiotic & MIC, $\mu \mathrm{g} / \mathrm{mL}$ & MIC interpretation \\
\hline Ampicillin & 0.25 & Susceptible \\
\hline Benzylpenicillin & 0.12 & Susceptible \\
\hline Ceftriaxone & $\leq 0.03$ & Susceptible \\
\hline Chloramphenicol & $\leq 0.5$ & Susceptible \\
\hline Erythromycin & Not reported & Susceptible \\
\hline Levofloxacin & $\leq 0.03$ & Susceptible \\
\hline Tetracycline & 0.5 & Susceptible \\
\hline Trimethoprim-sulfamethoxazole & $\leq 0.06$ & Susceptible \\
\hline
\end{tabular}

TABLE 1: Antibiotic MIC and sensitivities of the cultured Pasteurella

MIC: minimum inhibitory concentration

Subsequently, her therapeutic regimen was switched to penicillin G 24 million units IV by continuous infusion every 24 hours. Because of the presence of a mycotic aneurysm and the fact that the patient also had a prosthetic mechanical mitral valve, CT imaging of the chest and abdomen was carried out, which showed wedge-shaped hypodense areas in the spleen (Figure 2).

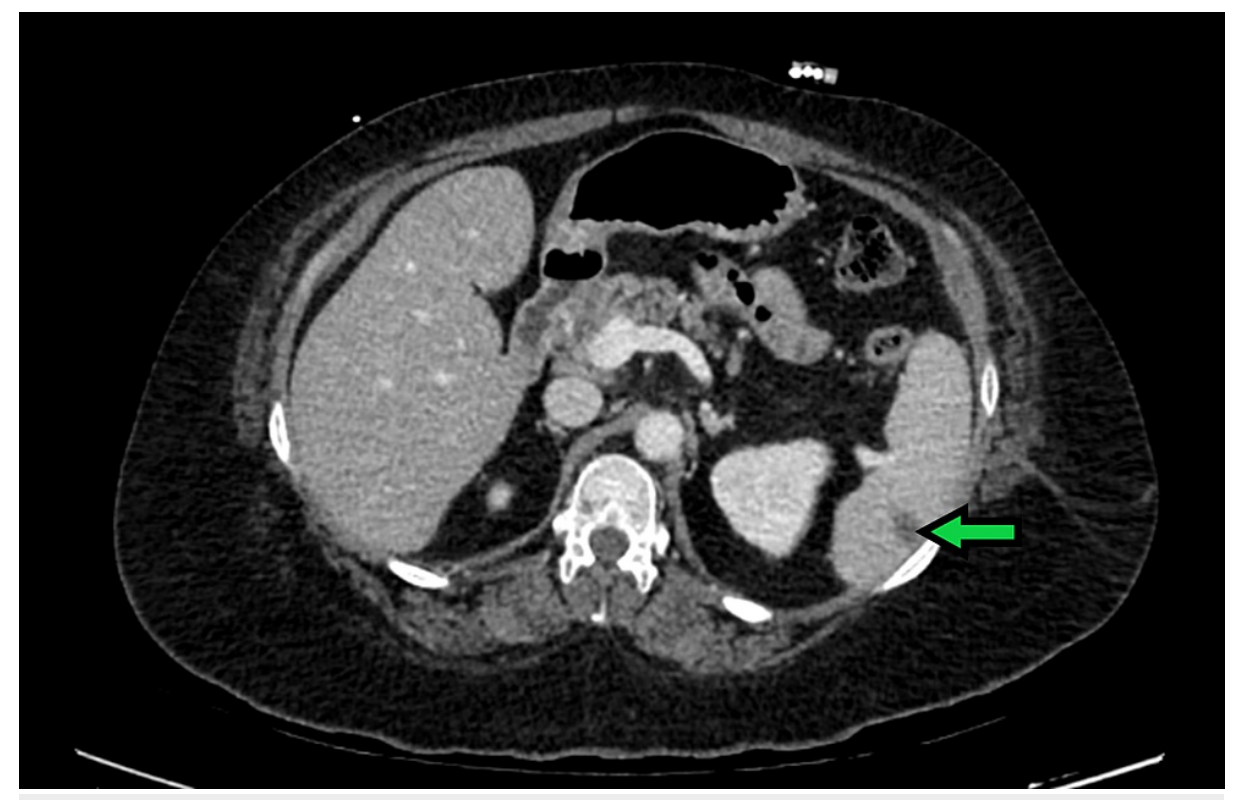

FIGURE 2: CT of the abdomen showing a wedge-shaped infarct of the spleen (arrow)

CT: computed tomography

Transesophageal echocardiogram (TEE) revealed 1-cm mobile vegetation on the mechanical mitral valve. Repeat blood cultures 48 hours after the initiation of antibiotics were negative for bacterial and fungal growth. A week postoperatively, the EVD was removed, and a repeat CT angiogram of the brain showed no evidence of residual aneurysm or arteriovenous malformation. A repeat TEE two weeks later revealed that the prosthetic mitral valve vegetation was increasing in size $(1.2 \mathrm{~cm})$ compared to the vegetation seen on the previous TEE. Hence, the patient underwent redo sternotomy, removal of the in-situ mechanical mitral prosthetic valve, and implantation of a mitral bioprosthetic valve. The mechanical mitral prosthetic valve that was surgically removed was negative for bacterial and fungal growth. Although the patient`s postoperative course was complicated by atrial fibrillation, her condition gradually improved, and she was discharged to a rehabilitation center to complete a six-week course of IV penicillin G 24 million units 
administered via continuous infusion every 24 hours, counting from the day of valve replacement. The patient was found to be doing well at her four-week follow-up appointment.

\section{Discussion}

Infective endocarditis usually involves the endocardial surface of the heart, and typically affects one or more heart valves. Prosthetic heart valves are particularly susceptible to endocarditis, as alterations to the flow characteristics of the valve encourage the deposition of microthrombi, to which pathogenic organisms adhere [4]. In cases of prosthetic valve endocarditis, the aortic valve is most frequently involved (69.1\%), followed by the mitral valve (50.4\%) [4]. Patients with infective endocarditis may present with one or more of a variety of symptoms (e.g., fever, chills, rigors, night sweats, malaise or fatigue, or embolic phenomena) and/or clinical manifestations, including new or changed murmur, focal neurological signs, splinter hemorrhages, Osler's nodes, Janeway lesions, Roth spots, or splenomegaly [5]. Our patient with prosthetic mitral valve endocarditis had, in addition to a typical presentation that included fever and a splenic infarct, the unusual complication of an acute intracranial hemorrhage due to the rupture of a cerebral mycotic aneurysm.

Cerebral mycotic aneurysms are rare, life-threatening lesions that develop due to the deterioration of intracranial or extracranial arterial walls caused by microbial infection [4]. One review has found that up to $65 \%$ of mycotic aneurysms originate from hematogenous spread from left-sided bacterial endocarditis, and further reported that 3-10\% of patients with infective endocarditis develop mycotic aneurysms [6]. The friable cardiac vegetations of infective endocarditis produce septic emboli that may lodge at distal branch points of the middle cerebral artery, thereby occluding the vasa vasorum and leading to infarction, infection, and aneurysm formation [6]. Mycotic aneurysms may result from fungal or viral infections, though the majority of them originate from bacteria, particularly Staphylococcus spp. and Streptococcus spp. [3]. Pasteurella spp. have been described as a cause of mycotic aneurysms in only nine previous cases (Table 2) [7-15], one of which involved a cerebral mycotic aneurysm [7]. This was reported in a 17-year-old male with amoxicillin-treated mitral valve endocarditis, whose mycotic aneurysm was not recognized until autopsy. 


\section{Cureus}

\begin{tabular}{|c|c|c|c|c|c|c|c|}
\hline Author (year) & $\begin{array}{l}\text { Patient } \\
\text { age, } \\
\text { Sex }\end{array}$ & Epidemiology & $\begin{array}{l}\text { Location of } \\
\text { aneurysm }\end{array}$ & $\begin{array}{l}\text { Associated Pasteurella } \\
\text { infection }\end{array}$ & Antimicrobials & $\begin{array}{l}\text { Surgical } \\
\text { procedure }\end{array}$ & Outcome \\
\hline $\begin{array}{l}\text { Pestana (1974) } \\
\text { [8] }\end{array}$ & $61, \mathrm{M}$ & $\begin{array}{l}\text { No bites } \\
\text { described; dogs } \\
\text { and cats at home }\end{array}$ & Abdominal aorta & $\begin{array}{l}\text { Left elbow and right first } \\
\text { middle carpal septic joints, } \\
\text { bacteremia }\end{array}$ & Penicillin G & $\begin{array}{l}\text { Open surgical } \\
\text { repair }\end{array}$ & $\begin{array}{l}\text { Died on the } \\
\text { operating table }\end{array}$ \\
\hline $\begin{array}{l}\text { Goldstein et al. } \\
\text { (1986) [9] }\end{array}$ & $61, F$ & Cat bite & Thoracic aorta & Not described & Not described & $\begin{array}{l}\text { Open surgical } \\
\text { repair }\end{array}$ & Not described \\
\hline $\begin{array}{l}\text { Thamlikitkul } \\
\text { and Sangruchi } \\
\text { (1990) [7] }\end{array}$ & $17, \mathrm{M}$ & $\begin{array}{l}\text { Denied animal bite } \\
\text { or contact }\end{array}$ & $\begin{array}{l}\text { Cerebral aneurysm } \\
\text { diagnosed on } \\
\text { autopsy }\end{array}$ & $\begin{array}{l}\text { Mitral valve endocarditis, } \\
\text { bacteremia }\end{array}$ & Ampicillin & None & Died from CVA \\
\hline $\begin{array}{l}\text { Balestra }(2000) \\
{[10]}\end{array}$ & $54, \mathrm{M}$ & $\begin{array}{l}\text { Dog lick, psoriatic } \\
\text { lesions }\end{array}$ & $\begin{array}{l}\text { Thoracic/abdominal } \\
\text { aorta }\end{array}$ & Bacteremia & $\begin{array}{l}\text { Amoxicillin, } \\
\text { gentamicin }\end{array}$ & $\begin{array}{l}\text { EVAR } \\
\text { performed one } \\
\text { year later }\end{array}$ & $\begin{array}{l}\text { Alive } 2 \text { years after } \\
\text { diagnosis }\end{array}$ \\
\hline $\begin{array}{l}\text { Koelemay } \\
\text { (2009) [11] }\end{array}$ & $64, \mathrm{M}$ & $\begin{array}{l}\text { Denied bites; cats } \\
\text { at home }\end{array}$ & Abdominal aorta & $\begin{array}{l}\text { Right leg cellulitis, no } \\
\text { bacteremia described }\end{array}$ & Cefotaxime & $\begin{array}{l}\text { Open surgical } \\
\text { repair }\end{array}$ & $\begin{array}{l}\text { Alive } 1 \text { year after } \\
\text { surgery }\end{array}$ \\
\hline $\begin{array}{l}\text { Cho et al. (2016) } \\
\text { [12] }\end{array}$ & $68, \mathrm{M}$ & Cat bite & Abdominal aorta & $\begin{array}{l}\text { Cellulitis of right thumb, } \\
\text { bacteremia }\end{array}$ & $\begin{array}{l}\text { Piperacillin- } \\
\text { tazobactam }\end{array}$ & $\begin{array}{l}\text { Open surgical } \\
\text { repair }\end{array}$ & $\begin{array}{l}\text { Died on day } 13 \\
\text { post-surgery from } \\
\text { septic shock }\end{array}$ \\
\hline $\begin{array}{l}\text { Shalan et al. } \\
\text { (2017) [13] }\end{array}$ & $69, F$ & Cat bite & Abdominal aorta & Bacteremia & Penicillin G & $\begin{array}{l}\text { EVAR followed } \\
\text { by open } \\
\text { surgical } \\
\text { procedure }\end{array}$ & $\begin{array}{l}\text { Alive } 8 \text { months } \\
\text { after surgery }\end{array}$ \\
\hline $\begin{array}{l}\text { Kano et al. } \\
(2020)[14]\end{array}$ & $61, M$ & Dog lick & $\begin{array}{l}\text { Abdominal aorta } \\
\text { and aortic arch }\end{array}$ & Bacteremia & Ampicillin & $\begin{array}{l}\text { Open surgical } \\
\text { repair }\end{array}$ & $\begin{array}{l}\text { Alive } 1 \text { year after } \\
\text { surgery }\end{array}$ \\
\hline $\begin{array}{l}\text { Jeng et al. } \\
(2020)[15]\end{array}$ & $61, \mathrm{M}$ & Dog bite & $\begin{array}{l}\text { Abdominal } \\
\text { aneurysm }\end{array}$ & Bacteremia & Not described & $\begin{array}{l}\text { Open surgical } \\
\text { repair }\end{array}$ & $\begin{array}{l}\text { Alive } 18 \text { months } \\
\text { after surgery }\end{array}$ \\
\hline Our Case (2021) & $57, \mathrm{~F}$ & $\begin{array}{l}\text { Dog lick, scratch } \\
\text { injuries }\end{array}$ & Cerebral aneurysm & $\begin{array}{l}\text { Mitral valve endocarditis, } \\
\text { bacteremia }\end{array}$ & Penicillin G & $\begin{array}{l}\text { Open surgical } \\
\text { clipping }\end{array}$ & $\begin{array}{l}\text { Doing well } 4 \\
\text { weeks after } \\
\text { surgery }\end{array}$ \\
\hline
\end{tabular}

\section{TABLE 2: Summary of Pasteurella mycotic aneurysm cases}

M: male; F: female; EVAR: endovascular aortic repair; CVA: cerebrovascular accident

Cerebral mycotic aneurysms are associated with high morbidity and mortality, approaching rates as high as $80 \%$ in ruptured and $30 \%$ in unruptured cases [16]. There are no standard treatment guidelines for cerebral mycotic aneurysms due to the rarity of the disease and the lack of randomized controlled trials; the management generally involves antimicrobial therapy for unruptured aneurysms and combined treatment involving antimicrobials and surgery for ruptures [6]. Surgical repair of a ruptured aneurysm may entail aggressive debridement of the infected tissue and reconstruction of the vasculature [6]. The choice of antimicrobials is guided by the susceptibilities of the infecting organism and the agent's capacity to penetrate the blood-brain barrier (BBB).

Our patient survived the catastrophic complication of a ruptured cerebral mycotic aneurysm thanks to the rapid recognition of the event, emergent surgical intervention, and initiation of broad-spectrum antimicrobial agents with excellent BBB penetration. Pasteurella spp. are invariably susceptible to penicillins, which can cross the $\mathrm{BBB}$ to maintain therapeutic concentrations in the central nervous system. The only other reported case of Pasteurella spp. cerebral mycotic aneurysm resulted in a fatal outcome, most probably due to a delay in diagnosis rather than in the commencement of treatment [7]. Our case underscores the utmost importance of detailed history and physical examination in the current era of high technology, and it highlights the value of prompt surgical and antimicrobial management to achieve optimal outcomes for patients with mycotic aneurysms in the cerebral vasculature.

\section{Conclusions}

Pasteurella spp. infection should be considered in the differential diagnosis when investigating the 
pathogenesis of mycotic aneurysm in patients who had initially sustained bites, other trauma, or inadvertent exposure of wounds, scratches, or ulcers to oral secretions of domestic animals. A joint surgical and infectious disease approach with prompt commencement of antimicrobial therapy is crucial in the management of mycotic aneurysms for achieving favorable outcomes. Delays in the presentation by patients or in diagnosis by healthcare providers may result in substantial morbidity and mortality. Finally, choosing an antimicrobial agent with excellent BBB penetration is essential for the successful treatment of mycotic cerebral aneurysms.

\section{Additional Information \\ Disclosures}

Human subjects: Consent was obtained or waived by all participants in this study. Conflicts of interest: In compliance with the ICMJE uniform disclosure form, all authors declare the following: Payment/services info: All authors have declared that no financial support was received from any organization for the submitted work. Financial relationships: All authors have declared that they have no financial relationships at present or within the previous three years with any organizations that might have an interest in the submitted work. Other relationships: All authors have declared that there are no other relationships or activities that could appear to have influenced the submitted work.

\section{References}

1. Porter RS, Hay CM: Pasteurella endocarditis: a case report and statistical analysis of the literature . Case Rep Infect Dis. 2020, 2020:8890211. 10.1155/2020/8890211

2. Wilson BA, Ho M: Pasteurella multocida: from zoonosis to cellular microbiology . Clin Microbiol Rev. 2013, 26:631-55. 10.1128/CMR.00024-13

3. Nakwan N, Nakwan N, Atta T, Chokephaibulkit K: Neonatal pasteurellosis: a review of reported cases . Arch Dis Child Fetal Neonatal Ed. 2009, 94:F373-6. 10.1136/adc.2008.143982

4. Wang A, Athan E, Pappas PA, et al.: Contemporary clinical profile and outcome of prosthetic valve endocarditis. JAMA. 2007, 297:1354-61. 10.1001/jama.297.12.1354

5. Murdoch DR, Corey GR, Hoen B, et al.: Clinical presentation, etiology, and outcome of infective endocarditis in the 21st century: the International Collaboration on Endocarditis-Prospective Cohort Study. Arch Intern Med. 2009, 169:463-73. 10.1001/archinternmed.2008.603

6. Ducruet AF, Hickman ZL, Zacharia BE, Narula R, Grobelny BT, Gorski J, Connolly ES Jr: Intracranial infectious aneurysms: a comprehensive review. Neurosurg Rev. 2010, 33:37-46. 10.1007/s10143-009-0233-1

7. Thamlikitkul V, Sangruchi T: Pasteurella multocida infective endocarditis: a case report . J Med Assoc Thai. 1990, 73:704-6.

8. Pestana OA: Mycotic aneurysm and osteomyelitis secondary to infection with Pasteurella multocida . Am J Clin Pathol. 1974, 62:355-60. 10.1093/ajcp/62.3.355

9. Goldstein RW, Goodhart GL, Moore JE: Pasteurella multocida infection after animal bites . N Engl J Med. 1986, 315:460.

10. Balestra B: Mycotic aneurysms of the aorta caused by infection with Pasteurella multocida . Clin Infect Dis. 2000, 31:E1-2. 10.1086/314039

11. Koelemay MJ: Pasteurella multocida infection, a rare cause of mycotic abdominal aortic aneurysm . J Vasc Surg. 2009, 50:1496-8. 10.1016/j.jvs.2009.06.052

12. Cho DD, Berliner Y, Carr D: Deadly case of Pasteurella multocida aortitis and mycotic aneurysm following a cat bite. World J Clin Cases. 2016, 4:142-5. 10.12998/wjcc.v4.i6.142

13. Shalan A, Wilson N, Poels J, Ikponmwosa A, Cavanagh S: The case of the neighbour's cat causing a symptomatic (mycotic) aortic aneurysm and an infected endograft. EJVES Short Rep. 2017, 37:18-21. 10.1016/j.ejvssr.2017.10.002

14. Kano Y, Takamatsu A, Honda H: Mycotic aneurysm due to Pasteurella multocida . QJM. 2020, 113:667-9. 10.1093/qjmed/hcaa020

15. Jeng EI, Acosta G, Martin TD, Upchurch GR Jr: Pasteurella multocida infection resulting in a descending thoracic aorta mycotic pseudoaneurysm. J Card Surg. 2020, 35:2070-2. 10.1111/jocs.14776

16. Nakahara I, Taha MM, Higashi T, et al.: Different modalities of treatment of intracranial mycotic aneurysms: report of 4 cases. Surg Neurol. 2006, 66:405-9. 10.1016/j.surneu.2006.01.021 